\section{$014-015$ \\ Noticias y comentarios \\ PH49 - Julio 2004}

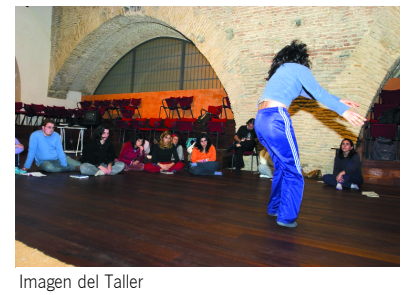

\title{
El CAAC propone analizar la danza como lenguaje artístico
}

Con la participación de Valie Export y Lili Dujurie, la realización del taller itinerante Retahílas: Trayectos y Tangentes entre la Danza, la Coreografia y la Performance se ha enmarcado en el conjunto de actividades que propone el Centro Andaluz de Arte Contemporáneo con el objetivo de analizar posibles relaciones entre las artes visuales, las políticas de género y la utilización de la tecnología en la práctica artística. Uno de los objetivos era resaltar el interés por reforzar la unión interdiciplinar entre la danza, el arte y la ciencia y situar a la danza como lenguaje artístico a parte entera. El taller se desarrolló en diferentes lugares de la ciudad de Sevilla (Reales Atarazanas, Paraninfo de la Universidad de Sevilla, espacio de investigación Endanza, diferentes dependencias del Centro Andaluz de Arte Contemporáneo y del Instituto Andaluz de Patrimonio Histórico).

Dentro de las reivindicaciones y las cuestiones que quisimos responder a lo largo del taller destacaríamos: ¿podriamos repensar en la coreografía, como un útil femenino, la manera de los nuevos medios audiovisuales usados por las feministas de los años 70, ya que el uso del cuerpo es también un material inmediato? ¿podría ser la danza, como la performance, un medio para luchar contra la construcción de la feminidad impuesta desde lo masculino, por ejemplo rompiendo los estereotipos actuales que del cuerpo de la bailarina se tienen (delgadez, determinado canon estético, etc.)? ipodría ser también una manera de romper con la idea del cuerpo como decorativo, usándolo en otras aptitudes de rechazo a la estética dominante, revindicando el cuerpo como arquitectura, como geometría? ¿se podría romper desde la danza misma el carácter tradicional que se le reconoce de espectáculo y divertimento, llegando a usar el lenguaje co- reográfico como un medio de conocimiento y de reflexión? ¿es a través de la danza, una experiencia física en el espacio y de su percepción a través del propio cuerpo una manera de expresar la subjetividad, como es expresada a través de las filmaciones, creando diferentes realidades, creando diferentes relaciones e identidades? ¿puede la danza y la performance notarse? ies interesante para la danza y la performance el uso de esta notación? ¿es la danza un acto o puede ser lexicalizado?

En relación con la coreografia, comprobamos que este término por propia definición no es exclusivo sólo de la danza, sino que atañe a otras disciplinas artísticas donde la aplicación poética del lenguaje se realiza a través de los cuerpos, y que si generalizamos pudiéramos entender a estos como cualquier objeto susceptible de ser ordenado en el tiempo y en el espacio. Pudimos estudiar cómo sobre estas prácticas han influido el contexto político y social, otras corrientes artísticas y de pensamiento. También como se influencian entre sí los distintos lenguajes artísticos, proporcionándonos claves para elaborar el material coreográfico inherente a ambas prácticas, llegando a componer conjuntamente a partir de las propuestas de la performance y de la danza.

Los resultados han sido grosso modo un mayor conocimiento de la coreografía y del lenguaje coreográfico como un valor común a otras artes, y una mayor consideración de la danza como lenguaje artístico.

\section{Salud López}

Directora del Taller

\section{Creada la Plataforma de Asociaciones de Conservadores-Restauradores de España}

Objetivo: transmitir las carencias y mejoras de las condiciones de Conservación y Restauración del

Patrimonio, asi como las formativas y laborales

Más información:

ACRCLM

Web: www.restauradorclm.org Correo-e.: restauradorclm@iespana.es

$\mathrm{PH}$ 42, p. 10-11

I Premio de Arqueología: Memorial Josep Barberà i Farràs

Convoca: Sociedad Catalana de Arqueología

Objetivo: investigación acerca de cualquier aspecto relacionado con la arqueología sin limitación cronológica o territorial

Plazo de presentación: hasta el 3 de septiembre de 2004

Más información:

Sociedad Catalana de Arqueología

Tel.: 934585511 Fax: 934571182

Web: www.scarqueologia.com Correo-e.: sca@scarqueologia.com 